\title{
Micro-environmental Control for Efficient local Cooling
}

\begin{abstract}
Micro-environment is hereby defined as the air space and environment around a person that directly impacts his/her thermal sensation. Most existing HVAC systems condition the air of the entire room including the unoccupied space, which leaves a big potential to save energy. This study aims at evaluating the performance of three existing air terminal devices (ATDs) to locally remove enough heat from the micro-environment to manage the thermal balance so as not to sacrifice thermal comfort when the ambient unoccupied space temperature is increased by $2.2^{\circ} \mathrm{C}$ from $23.9^{\circ} \mathrm{C}$ to $26.1{ }^{\circ} \mathrm{C}$ in the summer to reduce the external cooling load. A computational fluid dynamics (CFD) model was developed, validated by full-scale chamber tests and applied to evaluate different configurations of the ATDs for local cooling. Results show that the predicted performance agreed well with the measurements, and the selected ATD, with only $50 \mathrm{~W}$ cooling power, was always able to remove a sufficient amount of heat from the microenvironment in a room of raised temperature, when the manikin was moved inside a semicircle movement range. The cooling performance of the jet was increased more by increasing the supply air flow rate than reducing the supply temperature and was highly dependent on the shooting angle. The heat flux from the manikin surface is very sensitive to the surface temperature and furniture placement, and proper specification of the surface temperature is crucial for the CFD simulation to match the measured results.
\end{abstract}

\section{Key Words}

Micro-environment; thermal balance; CFD; local cooling

\section{Introduction}

Heating, ventilation and air conditioning (HVAC) consumes approximately $20 \%$ of the total energy use in developed countries [1] and about $13 \%$ in the United States [2]. Reducing energy consumption by HVAC 
systems hence plays an important role in improving the building's overall energy efficiency. The conventional HVAC system is typically called a total volume heating or cooling system which assumes that the entire indoor air space is conditioned. It results in not only a huge waste of energy for conditioning the unoccupied space but also inevitable discomfort for some occupants. It was reported that individuals had different thermal sensations under the conventional HVAC system due to variation in gender, age, body mass, clothing habits, metabolic rate, and thermal adaptation [3-5]. ASHRAE Standard 55 [6] defines thermal comfort conditions under which $80 \%$ of the occupants would be satisfied. However, in a large office building survey study, only $11 \%$ of the buildings achieved the $80 \%$ criteria [7].

Micro-environment refers to the perceived real and imaginary space around a person that directly impact one's personal environmental quality. A personal environmental control (PEC) system or a microenvironmental control system $(\mu \mathrm{X})$ is defined as a system which delivers thermal comfort and air quality for the micro-environment $[8,9]$. It is reported that a PEC can provide four times better air quality than the mixing ventilation and maintain the same level of thermal comfort with only $1 / 5$ of the conditioned air [10]. It is also capable of reducing the intensity of sick building syndrome (SBS) symptoms as well as increasing occupants' productivity [11,12].

The strategy of using local cooler air to improve occupants' thermal comfort is suggested by many standards [13] and is also an effective way to reduce the building's total energy cost. The building's energy cost, mostly HVAC cost, is driven by the cooling or heating load of the building which is proportional to the temperature difference between indoor and outdoor air according to the Fourier's law for heat transfer [14]. The typical thermostat set-point range inside a building is within $2.2{ }^{\circ} \mathrm{C}\left(4 .{ }^{\circ} \mathrm{F}\right)$. Several published findings have indicated the significant energy saving potential by expanding the temperature set-point range (increasing the set-point in the summer and reducing the set-point in the winter) [15]. Simulation analysis has shown that expanding the set-point range from $21.4-23.9{ }^{\circ} \mathrm{C}(70.5-$ 
$\left.75.0{ }^{\circ} \mathrm{F}\right)$ to $18.9-26.1{ }^{\circ} \mathrm{C}\left(66.0-79.0{ }^{\circ} \mathrm{F}\right)$ in a conventional HVAC building would reduce HVAC energy consumption by at least $20 \%$ depending on the location and climate [16].

Expanding the set-point range has to be supplemented by creating a local thermal envelope using the $\mu \mathrm{X}$ system around individuals to manage the thermal balance so that occupants' thermal comfort will not be sacrificed. A $\mu \mathrm{X}$ system is under develop. It consists of a micro-scale vapor compression system, of which the evaporator is embedded in the phase change material (PCM). The compression system is designed to run during the night to freeze the PCM to avoid dumping heat around the occupants as well as reduce the peak electricity rate. A certain amount of cooling is stored in the PCM and released as a cool breeze through a proper ATD to make the office worker comfortable for up to 10 hours during the day when the office room temperature is increased to $26.1^{\circ} \mathrm{C}\left(79.0^{\circ} \mathrm{F}\right)[17,18]$. In this way, although an extra portion of energy is consumed by the $\mu \mathrm{X}$ system during the night, the total cooling energy consumption is reduced by around $20 \%$ in 7 different climates in the U.S. based on an unpublished work done by our group.

In a simplified analysis proposed by U.S. Department of Energy based on the heat balance of a human body [19], a person sitting in an office is assumed to generate a total of $115 \mathrm{~W}$ (seated, very light work in offices), which is equal to the amount of heat that needs to be released to the surrounding environment to achieve thermal balance for the occupant. Among the $115 \mathrm{~W}, 70 \mathrm{~W}$ is considered to be sensible heat loss (convective and radiant) and $45 \mathrm{~W}$ is considered to be latent heat loss (evaporative and respiratory) [20]. This study only focused on the sensible part. The heat flow rate from the human body $q$ " under steady state can be expressed as:

$$
q^{\prime \prime}=A \cdot(1 / R) \cdot\left(T_{0}-T_{1}\right)
$$

Where $A$ is the body surface area $\left(\mathrm{m}^{2} / \mathrm{ft}^{2}\right), T_{0}$ is the averaged human surface temperature $\left({ }^{\circ} \mathrm{C} /{ }^{\circ} \mathrm{F}\right), T_{1}$ is the ambient temperature (assuming the mean radiant temperature equals to the air temperature, ${ }^{\circ} \mathrm{C} /{ }^{\circ} \mathrm{F}$ ) 
and $\mathrm{R}$ is the total sensible thermal resistance $\left(\mathrm{m}^{2} \cdot \mathrm{K} / \mathrm{W} / \mathrm{ft}^{2} \cdot{ }^{\circ} \mathrm{F} \cdot \mathrm{h} / \mathrm{Btu}\right)$. If the thermal resistance does not change when $T_{1}$ changes to the raised set-point $T_{2}$, the change in heat flow rate $\Delta q$ " is:

$$
\Delta q^{\prime \prime}=A \cdot(1 / R) \cdot\left(T_{2}-T_{1}\right)
$$

Divide Eqn. 2 by Eqn. 1,

$$
\Delta q^{\prime \prime}=q^{\prime \prime} \cdot\left(T_{2}-T_{1}\right) /\left(T_{0}-T_{1}\right)
$$

Assuming that the surface temperature at a comfortable state is around $33.9^{\circ} \mathrm{C}\left(93.0^{\circ} \mathrm{F}\right)[21]$ for exposed parts (head and forearm) and $31.7^{\circ} \mathrm{C}\left(89.0^{\circ} \mathrm{F}\right)$ for clothed parts [10,22,23] which gives an averaged surface temperature around $32.0{ }^{\circ} \mathrm{C}\left(89.6^{\circ} \mathrm{F}\right)$ [24], when the ambient temperature changes from $23.9^{\circ} \mathrm{C}$ $\left(75.0{ }^{\circ} \mathrm{F}\right)$ to $26.1{ }^{\circ} \mathrm{C}\left(79.0^{\circ} \mathrm{F}\right)$, a difference of $19.2 \mathrm{~W}$ needs to be removed by the $\mu \mathrm{X}$ system. This calculation is a simplification of thermal comfort based on the heat balance of the people. The concept of thermal comfort has a much broader definition. Tests using a thermal manikin and human subjects will be conducted in the next stage after the product come out. More discussion about the thermal comfort will be addressed then.

Various studies have been done, either by experiments or simulations, to determine the heat transfer flow rates over a human body in a still-air or uniform wind condition. The most advanced method is using a human-shaped thermal manikin with the control of surface temperature or heat flux [25-27]. However, very few studies were conducted to investigate the effect of a single air jet on the heat transfer flow rates of a human body.

The objective of the present study is to develop and validate a CFD model, and use it to help investigate the effect of the supply condition on the jet cooling performance and evaluate the performance of three existing ATDs which can be implemented in the $\mu \mathrm{X}$ system for supplying sufficient cooling to remove a minimum of $19.2 \mathrm{~W}$ to restore an occupant's thermal balance when the ambient room air is raised by 2.2 ${ }^{\circ} \mathrm{C}\left(4{ }^{\circ} \mathrm{F}\right)$. 


\section{Methods}

\subsection{Overview}

The computational and experimental domain represented a full-scale office, $4.88 \mathrm{~m} \times 3.66 \mathrm{~m} \times 3.05 \mathrm{~m}$ $(16.00 \mathrm{ft} \times 12.00 \mathrm{ft} \times 10.00 \mathrm{ft})$, with a linear diffuser mixing system $($ Figure 1). A workstation was located in the center of the room. A laptop was placed on the desk, and a $\mu \mathrm{X}$ system was put under the desk to provide local cooling to the manikin. The $\mu \mathrm{X}$ system was of the size $0.42 \mathrm{~m} \times 0.19 \mathrm{~m} \times 0.48 \mathrm{~m}$ (16.54 in $\times 7.48$ in $\times 18.90$ in), which was about the size of a desktop computer. It sucked the air through the holes on two sides and supplied the air through an ATD. The cooling power, $P$, provided by the mockup $\mu \mathrm{X}$ system is calculated as

$$
P=\rho \cdot \dot{V} \cdot c_{p} \cdot\left(T_{1}-T_{j e t}\right)
$$

Where $\rho$ is the density of the air $\left(\mathrm{kg} / \mathrm{m}^{3} / \mathrm{lb} / \mathrm{ft}^{3}\right), \dot{V}$ is the supply air volume flow rate $\left(\mathrm{m}^{3} / \mathrm{s} / \mathrm{ft}^{3} / \mathrm{h}\right), c_{p}$ is the specific heat of the air $\left(\mathrm{J} /\left(\mathrm{kg} \cdot{ }^{\circ} \mathrm{C}\right) / \mathrm{Btu} /\left(\mathrm{lb} \cdot{ }^{\circ} \mathrm{F}\right)\right)$, and $T_{j e t}$ is the supply air jet temperature $\left({ }^{\circ} \mathrm{C} /{ }^{\circ} \mathrm{F}\right)$.

The $\mu \mathrm{X}$ system is designed to supply constant $50 \mathrm{~W}$ cooling power during the day of the summer, different combinations of supply flowrate and supply temperature were tested using CFD model and discussed in Section 3.3. The operating condition of the $\mu \mathrm{X}$ system was selected based on the evaluation of the cooling performance as well as the thermal comfort. Three types of ATDs were investigated (Figure 1). Type I was a single-diffuser ATD placed under the desk which has a diffuser area of $13.10 \mathrm{~cm}$ $\times 7.20 \mathrm{~cm}(5.16$ in $\times 2.84$ in). Type II was a round-diffuser ATD placed above the desk facing the occupant, and the diffuser had a radius of $5.50 \mathrm{~cm}(2.17 \mathrm{in})$. And Type III is a two-split-diffuser ATD placed under the desk, which had two diffusers with an area of $6.05 \mathrm{~cm} \times 7.20 \mathrm{~cm}(2.38 \mathrm{in} \times 2.84 \mathrm{in})$ each. A manikin with 20 separately heated segments was seated in an office chair in front of the desk to simulate an occupant working in the office. 

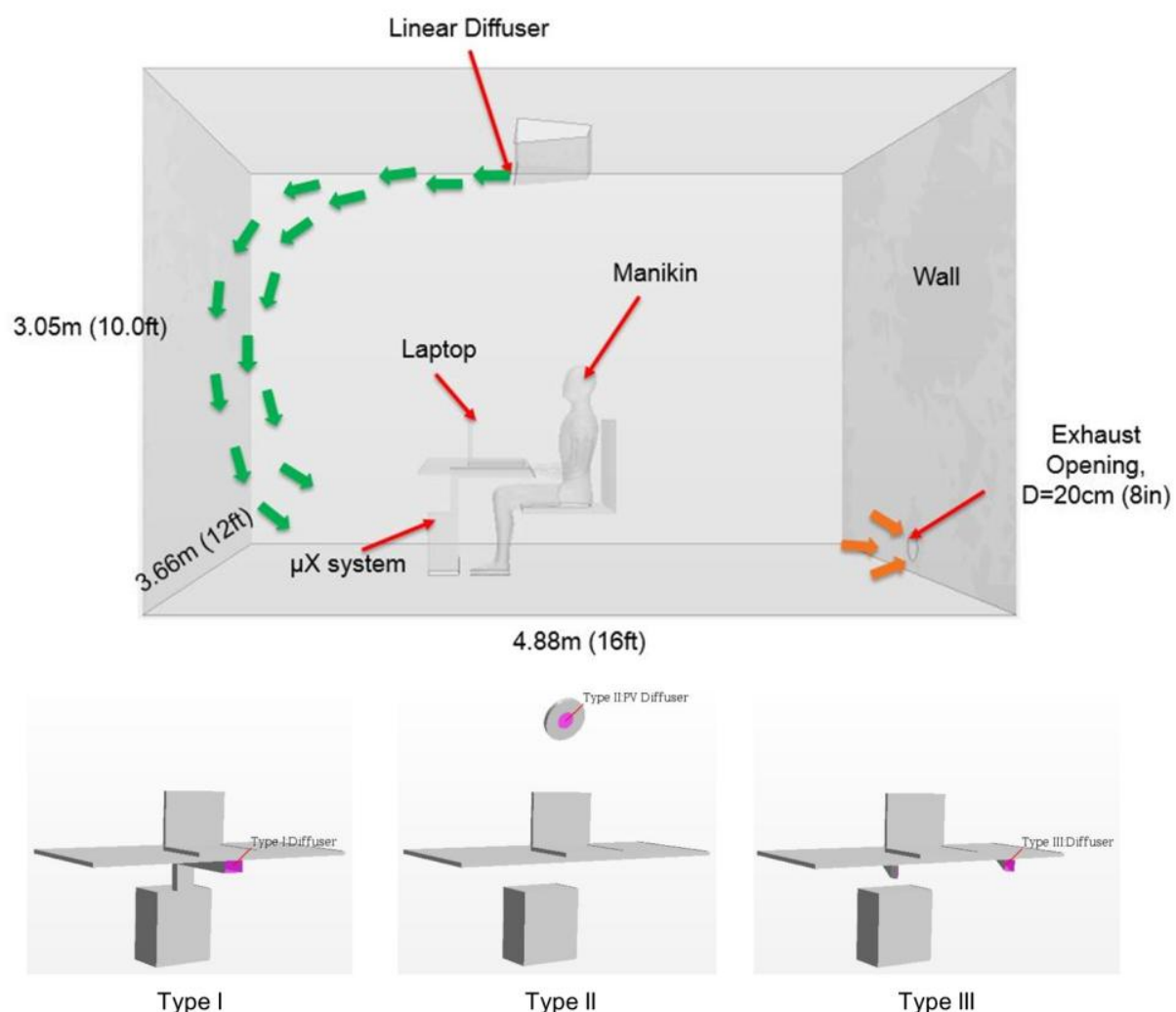

Figure 1 Computational domain and three types of ATDs studied

\subsection{Experimental Facility}

Full-scale laboratory testing has been used as a reliable testing method for indoor air quality, thermal management, and associated energy estimation studies [28-30]. The present work utilized a full-scale polished stainless steel chamber system which has the same dimension as the CFD model (Figure 2). An HVAC system was used for conditioning the chamber, and the room temperature was controlled by the return air temperature. A linear air diffuser was constructed to provide better-defined boundary conditions for comparison with the CFD simulations. The inlet had the dimensions of $0.017 \mathrm{~m} \times 0.900 \mathrm{~m}(0.669 \mathrm{in} \times$ $35.433 \mathrm{in})$. The supply air flow rate was set at $0.075 \mathrm{~m}^{3} / \mathrm{s}(160 \mathrm{cfm})$ which corresponded to an air change rate of $5 \mathrm{~h}^{-1}$. The supply air jet was directed to the wall of the chamber and then distributed to the rest of the room before it was exhausted. The supply velocity is around $4.9 \mathrm{~m} / \mathrm{s}(965 \mathrm{fpm})$ which is a little higher than the design velocity of $4.1 \mathrm{~m} / \mathrm{s}(800 \mathrm{fpm})$. However, the main purpose of the linear diffuser is to 
create a uniformly mixing condition in the occupied space as well as minimize the local draft on the manikin.

In order to make sure that the environment inside the chamber is fully mixed, three temperature trees using thermistors were placed around the manikin, measuring the temperature at six different heights, $0.10 \mathrm{~m}$ (3.94 in), $0.40 \mathrm{~m}$ (15.75 in), $0.70 \mathrm{~m}$ (27.56 in), $1.00 \mathrm{~m}$ (39.37 in), $1.30 \mathrm{~m}$ (51.18 in), and $1.50 \mathrm{~m}$ (59.06 in). Since it was reported that the thermal plume of the manikin was about $0.20 \mathrm{~m}$ (7.87 in) thick $[31,32]$, two temperature trees were placed $0.30 \mathrm{~m}$ (11.81 in) away from the side of the manikin, and the other one was placed $1.00 \mathrm{~m}$ (39.37 in) behind the manikin. Ten thermocouples were also used in this study to monitor the surface temperature of the chamber wall (two on the floor, two on the ceiling, two on each side wall and one on each end wall). To make sure no draft except the $\mu \mathrm{X}$ supply air was perceived by the manikin, air velocity measurement was taken with hot-sphere anemometers on the left of the manikin at the same heights of the temperature measurement. A 20-segment manikin, which was made to represent a $50^{\text {th }}$ percentile Western Male body form with a total surface area of $1.8 \mathrm{~m}^{2}\left(19.4 \mathrm{ft}^{2}\right)$ and height of $1.80 \mathrm{~m}(5.91 \mathrm{ft})$, was sitting by the desk to simulate a working person. Temperature and heat flux sensors were distributed over each segment of the manikin to monitor or control the surface temperature and heat flux. In this study, the manikin's surface temperatures were controlled at set-points, while allowing the heat flux to vary with the environmental condition. The head, face, and forearms were set to be $33.9^{\circ} \mathrm{C}\left(93.0{ }^{\circ} \mathrm{F}\right)$ to represent exposed skin surface, and the other segments were set to be $31.7^{\circ} \mathrm{C}\left(89.0^{\circ} \mathrm{F}\right)$ which represents surfaces of light clothing $[10,22]$. The heat flux through each segment was monitored and recorded for comparison with the CFD simulation results. 


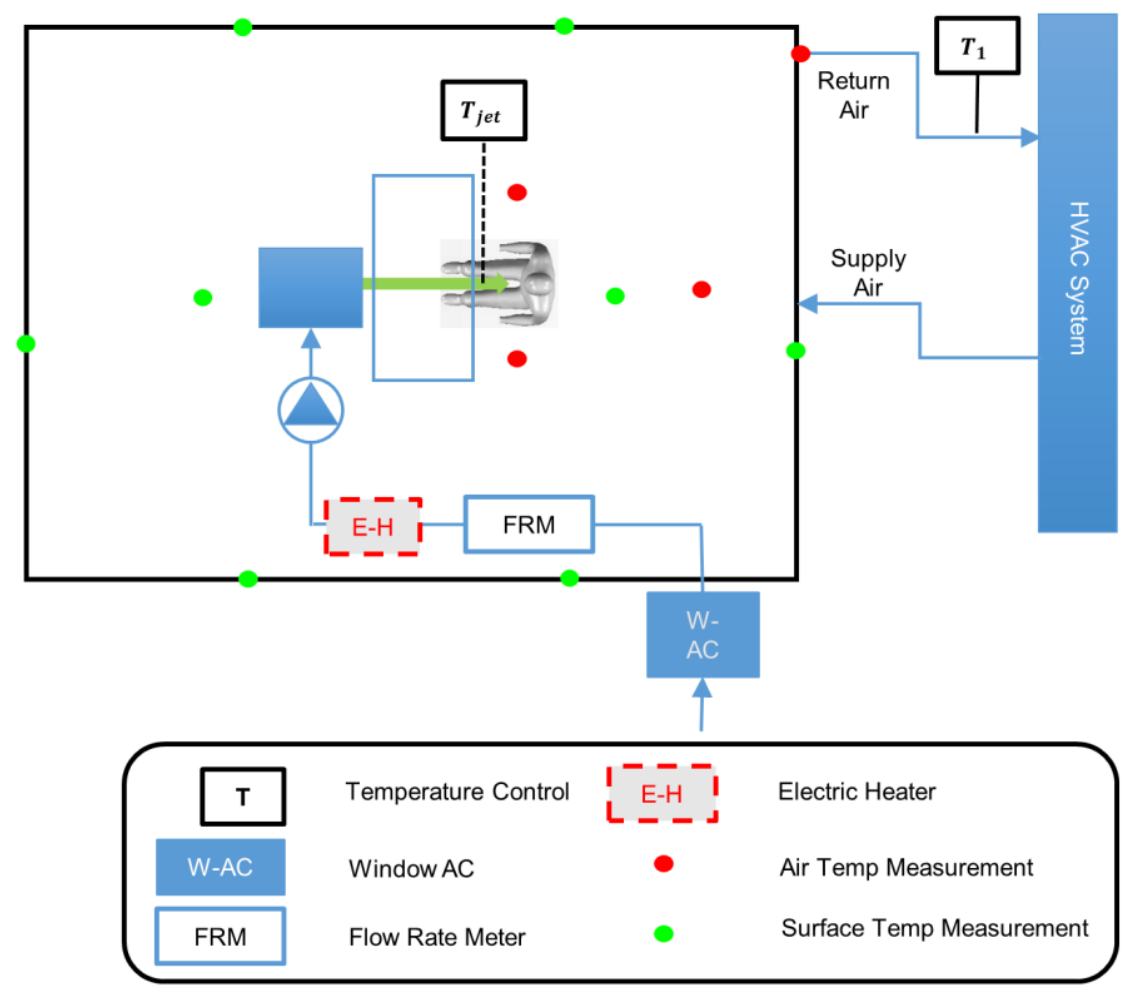

Figure 2 Schematic of the test chamber

Inside the chamber, a mockup $\mu \mathrm{X}$ system was built. The system consisted of a window air conditioning unit, an orifice flange flow rate meter, an in-duct fan, a plenum box, an electric heater, an air diffuser and connecting ducts between them (Figure 2). Different from the real $\mu \mathrm{X}$ system, instead of sucking air from its immediate surroundings inside the room, the window air conditioner was put outside the chamber to supply overcooled air $\left(\sim 10{ }^{\circ} \mathrm{C} / 50{ }^{\circ} \mathrm{F}\right)$ through a hole in the chamber wall in order to minimize the disturbance to the chamber's airflow and prevent the exhaust heat from the window air conditioner from going into the chamber. The overcooled air was reheated to the set-point before it was supplied to the manikin. 


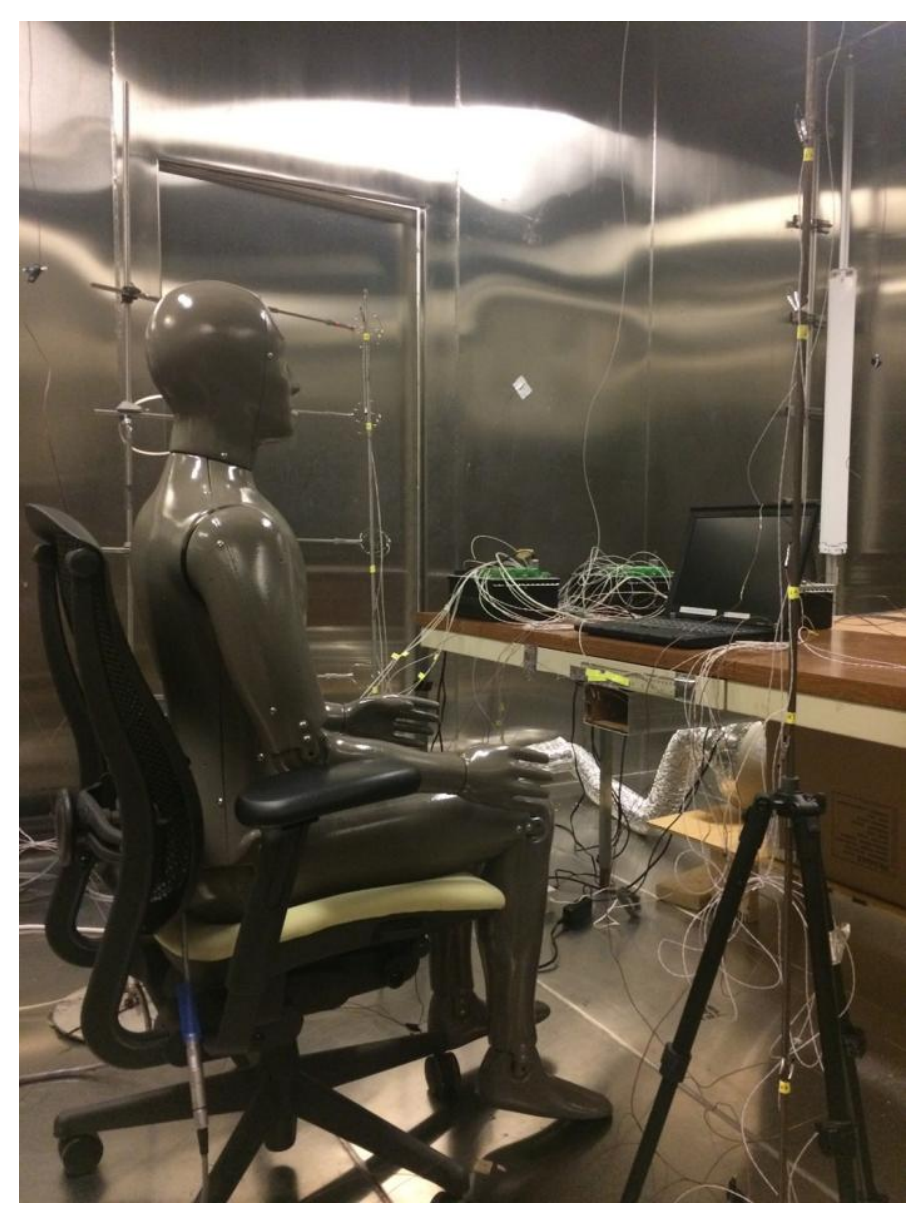

Figure 3 Experimental Facility

\subsection{Computational Model}

Computational Fluid Dynamics (CFD) is a simulation technique that predicts the flow field and parameters in it by solving a series of fluid mechanic equations. Compared to experimental test, CFD simulation is less costly in time and material and can give a reasonably good prediction of the detailed information about the flow field. These features make CFD widely used in the first stage of many industrial designs, especially for indoor environmental systems [26]. Since the flow field in the indoor environment is often turbulent, the most challenging problem of CFD is how to model the turbulence properly. A wide variety of turbulence models has been developed and employed in the indoor environment modeling, including Reynolds-averaged Navier-Stokes equations (RANS), Detached Eddy Simulation (DES), and Large Eddy Simulations (LES) techniques. A lot of research has been done on 
evaluating different turbulence models in simulating indoor air flows [22,29,33-35]. The general conclusion drawn from these studies is that the performance of those turbulence models is problemdependent, and the $k-\varepsilon$ family performed reasonably well in most cases [36]. This study followed the guidelines developed by Dygert et al. [22] on selecting the turbulence model and setting the boundary conditions.

All CFD simulations in this study were performed using a commercial CFD software (STAR-CCM+ 9.04.011). This software utilizes a more user-friendly interface and includes almost every function needed for CFD simulation including creating the geometry, generating the mesh, calculating and post-processing. It has been used more and more in recent years and performed well compared to other software [35].The flow field was calculated as incompressible ideal gas based on the standard $k-\varepsilon$ turbulence model in combination with a two-layer wall treatment model. It enables the turbulent dissipation rate $\varepsilon$ and turbulent viscosity $v_{t}$ to be calculated smoothly from the freestream through the buffer layer to the viscous sub-layer [10]. All the equations were solved with the SIMPLE algorithm and a second-order accurate scheme. Since the chamber space is symmetric, the computational domain of half of the chamber was first created using the commercial grid-generation software Pointwise and then the grids were regenerated using STAR-CCM+. Polyhedral grids with prism layer mesh were used in this study. A rather fine grid (around 5M cells) was applied around the manikin (Figure 4). In order to generate a mesh with good discretization, the surface and volume mesh was generated based on the guideline given by Russo [37]. The surface cells on the manikin varied from $2.50 \mathrm{~mm}(0.10 \mathrm{in})$ to $10.00 \mathrm{~mm}$ (0.39 in) and twenty layers of prism cells were distributed all over the surface in a total thickness of $25.00 \mathrm{~mm}(0.98 \mathrm{in})$ with a stretching ratio of 1.2. This gave a $y+$ value on the surface of the manikin lower than 0.8 which was considered to be sufficiently good. A relatively uniform mesh was applied in the mixing region between the manikin and the diffuser. The length scale of the surface cell of the diffuser was on the order of 2.00 $\mathrm{mm}(0.08 \mathrm{in})$. 


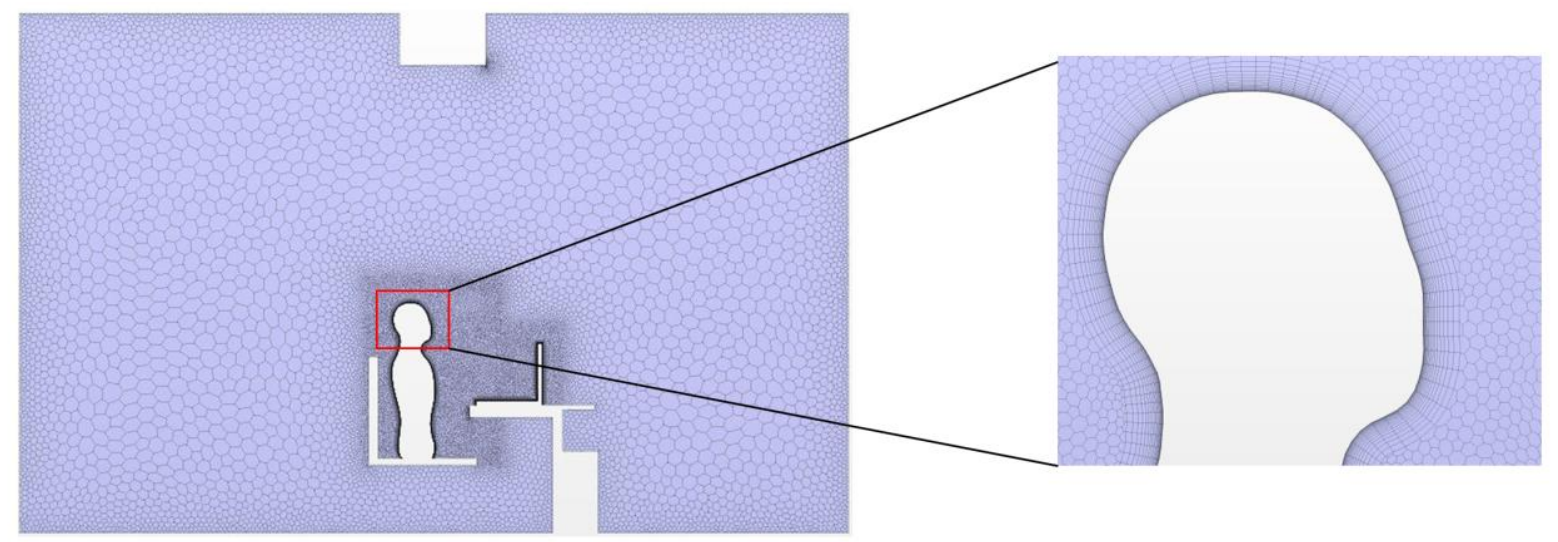

Figure 4 Mesh grids of the CFD model

\subsection{Boundary Conditions Used in CFD Simulation}

This paper summarized two parts of this work. The first part was validating the CFD model. In this part of work, CFD simulation results were compared with experimental measurements. Two validation cases were run and compared with experimental data. One was for the manikin sitting in a room of raised temperature $\left(26.1{ }^{\circ} \mathrm{C} / 79.0{ }^{\circ} \mathrm{F}\right)$ without the $\mu \mathrm{X}$ system (Case I), and the other one was for the manikin sitting in a room of raised temperature $\left(26.1{ }^{\circ} \mathrm{C} / 79.0{ }^{\circ} \mathrm{F}\right)$ with the $\mu \mathrm{X}$ system (Case II). The boundary conditions of the cases for validation are summarized in Table 1.

Table 1 Boundary Conditions for Validation

\begin{tabular}{lll}
\hline Surface & Boundary Condition Type & Setting \\
\hline Ceiling & Constant Temperature & $25.7^{\circ} \mathrm{C}\left(78.3^{\circ} \mathrm{F}\right)$ for Case I; \\
& $25.5^{\circ} \mathrm{C}\left(77.8^{\circ} \mathrm{F}\right)$ for Case II \\
\hline Floor & Constant Temperature & $24.3^{\circ} \mathrm{C}\left(75.8^{\circ} \mathrm{F}\right)$ for Case I; \\
\hline Manikin Head, Face and & $24.5^{\circ} \mathrm{C}\left(76.1^{\circ} \mathrm{F}\right)$ for Case II \\
Forearm & Constant Temperature & $33.9^{\circ} \mathrm{C}\left(93.0^{\circ} \mathrm{F}\right)$ \\
\hline Remaining Manikin Surface & Constant Temperature & $31.7^{\circ} \mathrm{C}\left(89.0^{\circ} \mathrm{F}\right)$ \\
\hline
\end{tabular}


Turbulrnce Intensity (T.I.) $=0.1$;

Linear Diffuser $\quad$ Velocity Inlet

Turbulent Length Scale $=0.0023$

$\mathrm{m}$;

$27.8^{\circ} \mathrm{C}\left(82.4^{\circ} \mathrm{F}\right)$ for Case I;

$28.3^{\circ} \mathrm{C}\left(82.9^{\circ} \mathrm{F}\right)$ for Case II

\begin{tabular}{lll}
\hline Exhaust Opening & Pressure Outlet & N/A \\
\hline$\mu$ X system Diffuser (Type I) & Velocity Inlet & Measured Vel. \& T.I.; \\
& & Turbulent Length Scale $=0.0065$ \\
& & $\mathrm{~m} ;$ \\
\hline Laptop & Heat Source & $23.09{ }^{\circ} \mathrm{C}\left(73.6{ }^{\circ} \mathrm{F}\right)$ for Case II \\
\hline Symmetric Plane & Symmetry Plane & $17.0 \mathrm{~W}$ \\
\hline The Other Surfaces & Adiabatic Wall & N/A \\
\hline
\end{tabular}

The percentage of radiant heat loss from an occupant is significant, ranging from $50 \%$ to $66 \%$ [38]. It is, therefore, important to get an accurate account of the radiant heat loss for predicting the total heat loss. According to the law of radiant heat transfer between gray surfaces, the radiant heat transfer $Q_{1-2}$ between surface 1 and 2 is governed by:

$$
Q_{1-2}=\frac{\sigma\left(T_{s 1}^{4}-T_{s 2}^{4}\right)}{\frac{1-\varepsilon_{1}}{\varepsilon_{1} A_{1}}+\frac{1}{A_{1} F_{1,2}}+\frac{1-\varepsilon_{2}}{\varepsilon_{2} A_{2}}}
$$

where $\sigma$ is the Stefan-Boltzmann constant $\left(5.67 \times 10^{-8} \mathrm{~W} /\left(\mathrm{m}^{2}-\mathrm{K}^{4}\right)\right)$, and $T_{s 1}$ and $T_{s 2}$ are the absolute temperature of surface 1 and $2(\mathrm{~K}), \epsilon_{1}$ and $\epsilon_{2}$ are the emissivity of surface 1 and $2, A_{1}$ and $A_{2}$ are the area of surface 1 and $2\left(\mathrm{~m}^{2}\right)$, and $F_{1,2}$ is the view factor from surface 1 to 2 . Therefore, the emissivity and 
temperature of all the surfaces have to be determined ahead of the simulation. In this study, the emissivity of the manikin surface was given by the manufacturer as 0.92 , and the emissivity of the surrounding chamber wall was assumed to be 0.27 (polished stainless steel, obtained from the material specification). The surface temperature used in the simulation was obtained from experimental measurements.

The inlet velocity (Figure 5) of the $\mu \mathrm{X}$ system diffuser was set in the computational model to match the experimental setup. A total air flow rate of $0.014 \mathrm{~m}^{3} / \mathrm{s}(29.0 \mathrm{cfm})$ was used in the simulation with a maximum velocity of $2.2 \mathrm{~m} / \mathrm{s}$. Values for turbulent intensity varied in the experiment from $5.0 \%$ to $15.0 \%$. A value of $10.0 \%$ was used in the simulation throughout for simplification.
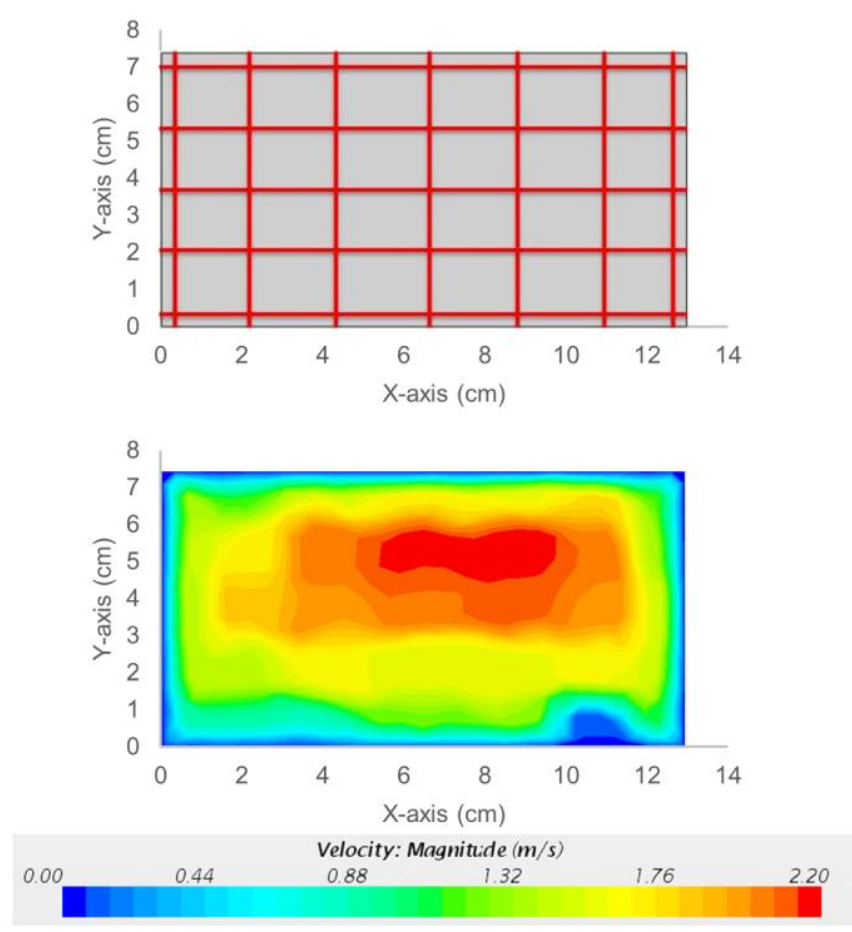

Figure 5 Velocity traverse grid and profile of the diffuser (Type I)

The second part of this work is evaluating the performance of different ATDs in cooling the manikin. The CFD cases simulated the scenario that the office room was kept at $26.1^{\circ} \mathrm{C}\left(79.0^{\circ} \mathrm{F}\right)$, i.e. $2.2^{\circ} \mathrm{C}\left(4.0^{\circ} \mathrm{F}\right)$ higher than the normal set-point for cooling. Room supply air of certain temperature was provided to the chamber to make the exhaust air temperature to be $26.1{ }^{\circ} \mathrm{C}\left(79.0{ }^{\circ} \mathrm{F}\right)$. In this study, for the case without 
$\mu \mathrm{X}$ system, the supply temperature was kept at $25.4^{\circ} \mathrm{C}\left(77.8^{\circ} \mathrm{F}\right)$, and for the case with the $\mu \mathrm{X}$ system, the supply temperature was kept at $26.0^{\circ} \mathrm{C}\left(78.8^{\circ} \mathrm{F}\right)$. Also, since for a conditioned building the wall temperature (mostly internal walls) should be close to room temperature according to the heat balance, it is reasonable to apply $26.1^{\circ} \mathrm{C}\left(79.0^{\circ} \mathrm{F}\right)$ as the wall surface temperature. The $\mu \mathrm{X}$ system was designed to supply constant $50.0 \mathrm{~W}$ cooling power during the day in the summer. Different combinations of supply air temperatures and flow rates reflecting the $50 \mathrm{~W}$ cooling power according to Eqn. 4 were tested first and then the best combination was selected based on cooling performance and thermal comfort.

\subsection{Determination of the Convective Heat Transfer Coefficient}

This study calculated the natural convective heat transfer coefficient of each segment of a seated manikin using the results of the CFD simulations. The total heat flux of each segment $\dot{q}_{t}$ consists of radiant heat flux $\dot{q}_{r}$ and convective heat flux $\dot{q}_{c}$. And the convective heat flux equals to the product of the convective heat transfer coefficient $h$ and temperature difference between the surface $T_{0}$ and room air $T_{1}$.

$$
\dot{q}_{t}=\dot{q}_{r}+\dot{q}_{c}=\dot{q}_{r}+h \cdot\left(T_{0}-T_{1}\right)
$$

The convective heat transfer coefficient obtained in this study was compared with some previous studies [25-27]. de Dear et al. [25] used a purely experimental approach which measured the total sensible heat flux with a thermal manikin and isolated the convective part from it by covering the manikin with the low-emissivity material. The accuracy of this method depended on the measurement accuracy, including temperature and heat flux measurements. Yang et al. [27] used a hybrid method, with which they measured the total sensible heat flux using a thermal manikin and subtracted the radiant heat flux obtained from numerical simulation to get the convective heat flux. The accuracy of this method also depended on the accuracy of the measurement since obtaining the radiant heat flux by numerical simulation also required accurate surface temperature measurement. Sørensen and Voigt [26], as well as the current work, used CFD models to calculate the convective heat flux by solving a series of fluid mechanics equations. The accuracy of this method depended on the use of the turbulence model and grid quality. 


\section{Results and Discussion}

\subsection{Validation}

As mentioned earlier, the validation work included two cases, with and without the $\mu \mathrm{X}$ system. Case I dealt with the flow field without the $\mu \mathrm{X}$ system, in which the natural convection dominated the heat exchange between the manikin and ambiance. Case II focused on the flow field with the $\mu \mathrm{X}$ system, in which both the natural and forced convection played important roles.

The total heat loss from the manikin as well as the averaged heat flux of each segment was recorded and compared with the CFD results. For the case without the $\mu \mathrm{X}$ system, the total heat loss predicted by CFD was $74.4 \mathrm{~W}$. Compared to the total heat loss by experiment $74.0 \mathrm{~W}$, the error was about $0.5 \%$. The heat flux distribution over the 20 segments also agreed well with the measured data (Figure 6). For the case with the $\mu \mathrm{X}$ system, the CFD simulation gave a total heat loss of $108.3 \mathrm{~W}$. Compared to the total measured heat loss of $115.1 \mathrm{~W}$, the error was around $5.9 \%$. These errors are smaller than those found in previous studies [39]. The heat flux distribution gave a more detailed description of the source of the error. A significant discrepancy was observed for the stomach as well as the back part of the manikin, which the air was blowing onto. One explanation would be that the CFD model under-predicted the forced convective heat transfer from the manikin. Another explanation was that the manikin did not maintain the same surface temperature as in the simulation. According to the description of the manufacturer, the manikin surface temperature of each segment was controlled by a distributed sensor wire and a distributed heating wire. Even though they claimed that the temperature distribution over each segment was very uniform, an obvious non-uniformity of temperature was still observed because it is not possible to control the surface temperature everywhere. This non-uniform surface temperature distribution was different with the boundary condition used in the CFD case, and therefore, was very likely to result in the difference in heat flux prediction. More discussion is included in Section 3.6. Nonetheless, the difference between the predicted and measured heat fluxes are relatively small and is considered to be acceptable for the purpose of evaluating different ATDs. 
$\mu \mathrm{X}$ Off
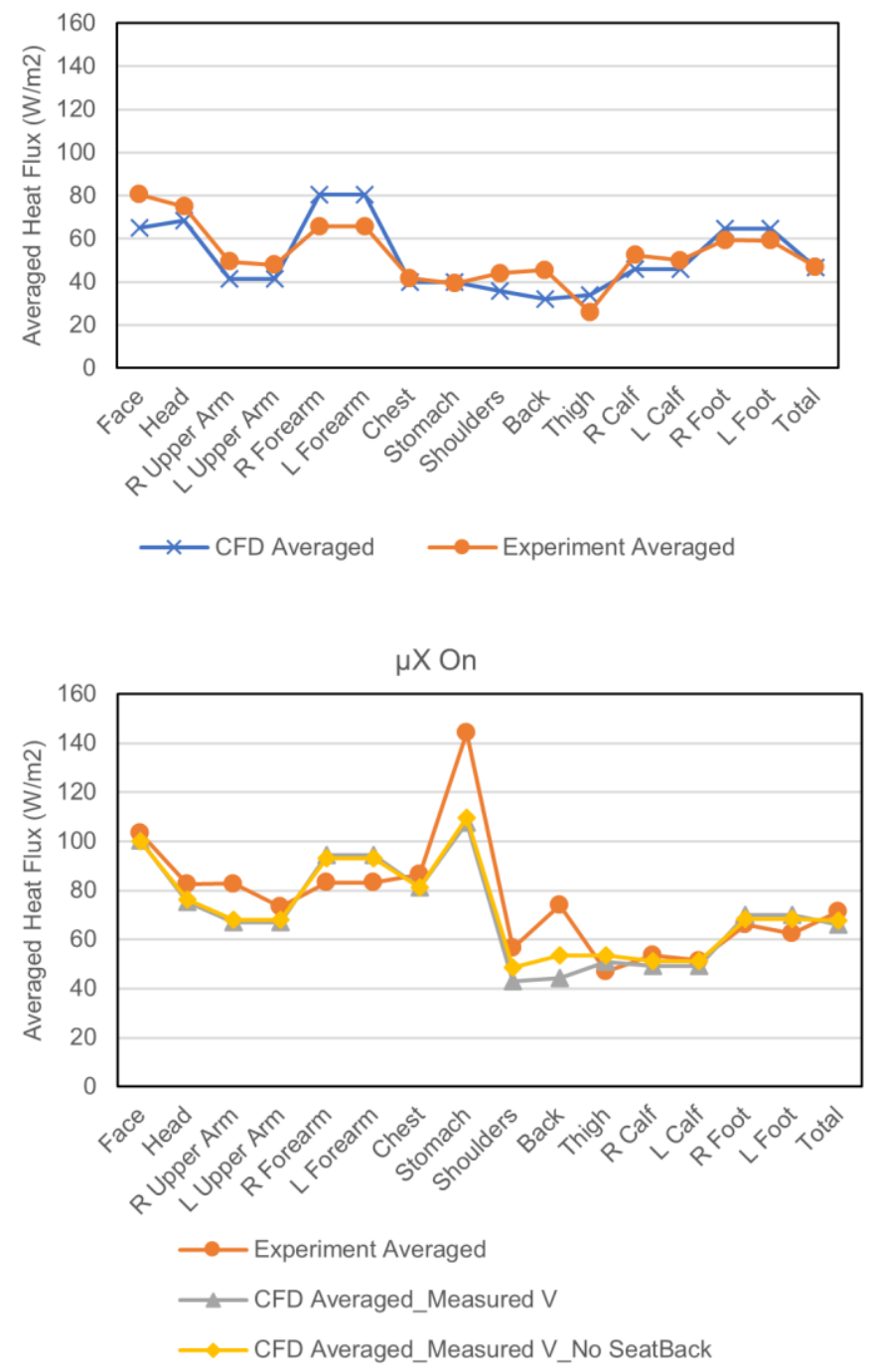

Figure 6 Comparison between CFD and experimental results

\subsection{Convective heat transfer coefficient of different body segments}

The current work calculated the convective heat transfer coefficient of each segment of a seated manikin.

Different with the work done by other researchers, this work was the only one using a manikin representing an adult male instead of a female. Figure 7 shows the comparison between the results of this 
study and their results. The comparatively better agreement was observed for the chest, back, thigh, pelvic, and foot while larger variances were obtained for the head, arm, and calf. This difference partially results from the different shape of the manikin. The difference in height, surface area and shape could change the development of the thermal boundary layer and thus the convective heat transfer coefficient. However, considering the difference between three previous studies, this reason may not be the primary one. A more convincing explanation could be that the ways used to calculate the convective heat flux were different in these works. As mentioned in Sec. 2.5, three methods were utilized in these works including the current work. Among these three methods, de Dear et al. [25] using the pure experiment seems to be the most reliable method assuming all the measurements were accurate enough because the other two methods involved numerical errors which were hard to quantify.

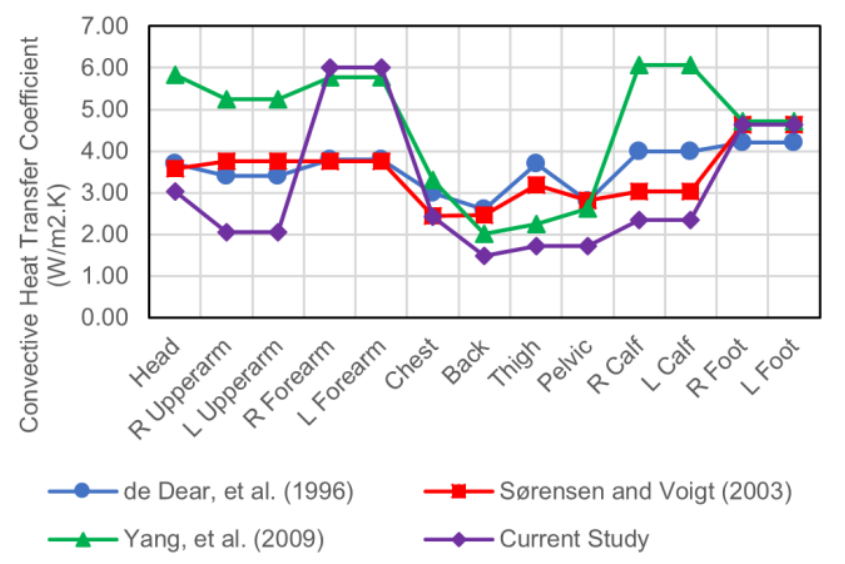

Figure 7 Convective heat transfer coefficient of different segments of the human body

\subsection{Determination of suitable air supply temperature and flow rates}

Localized cooling provided by the $\mu \mathrm{X}$ system sometimes can cause insufficient cooling or local discomfort if the supply condition, such as the target area, supply velocity, supply temperature, is not controlled properly. Since the $\mu \mathrm{X}$ system is designed to give $50.0 \mathrm{~W}$ of cooling during the work hours in the summer, several combinations of supply air temperature and flow rates (Table 2) were tested using the validated CFD model. The ambient air and surface temperature were kept at $26.1^{\circ} \mathrm{C}\left(79.0^{\circ} \mathrm{F}\right)$, and the 
manikin was placed $0.20 \mathrm{~m}$ (7.87 in) away from the desk. A rectangular air diffuser $(13.1 \mathrm{~cm} \times 7.2 \mathrm{~cm} /$ 5.16 in $\times 2.84$ in) was mounted under the desk aiming at the stomach of the manikin. The manikin surface was set as a constant temperature boundary which had a temperature of $33.9^{\circ} \mathrm{C}\left(93.0^{\circ} \mathrm{F}\right)$ on the head and $31.7^{\circ} \mathrm{C}\left(89.0^{\circ} \mathrm{F}\right)$ on the remaining surface. The total heat loss of each case with the $\mu \mathrm{X}$ system was subtracted by the total heat loss without the $\mu \mathrm{X}$ system to give the extra heat removed by the air jet.

\subsubsection{Cooling ability}

Table 2 shows the relationship between the extra heat removed by the air jet and the supply air flow rates as well as supply air temperature. While the flow rate ranged from $0.008-0.038 \mathrm{~m}^{3} / \mathrm{s}(17.2-81.0 \mathrm{cfm})$, the extra heat removed by the jet varied linearly with it even though the supply temperature was reduced. It is because when the flow rate increased, the velocity of the air blowing onto the manikin was also increased, resulting in an increase in the convective heat transfer coefficient.

Table 2 Cooling ability of different combinations of supply temperature and flow rates

\begin{tabular}{cccccc}
\hline Case & A & B & C & D & E \\
\hline Supply & $21{ }^{\circ} \mathrm{C}$ & $22{ }^{\circ} \mathrm{C}$ & $23{ }^{\circ} \mathrm{C}$ & $24{ }^{\circ} \mathrm{C}$ & $25^{\circ} \mathrm{C}$ \\
Temperature & $\left(69.8^{\circ} \mathrm{F}\right)$ & $\left(71.6^{\circ} \mathrm{F}\right)$ & $\left(73.4{ }^{\circ} \mathrm{F}\right)$ & $\left(75.2{ }^{\circ} \mathrm{F}\right)$ & $\left(77^{\circ} \mathrm{F}\right)$ \\
\hline Flow Rate & $0.008 \mathrm{~m}^{3} / \mathrm{s}$ & $0.010 \mathrm{~m}^{3} / \mathrm{s}$ & $0.014 \mathrm{~m}^{3} / \mathrm{s}$ & $0.020 \mathrm{~m}^{3} / \mathrm{s}$ & $0.038 \mathrm{~m}^{3} / \mathrm{s}$ \\
& $(17.2 \mathrm{cfm})$ & $(21.5 \mathrm{cfm})$ & $(29.4 \mathrm{cfm})$ & $(42.2 \mathrm{cfm})$ & $(81.0 \mathrm{cfm})$ \\
\hline Extra Heat & 22.5 & 25.8 & 33.5 & 44.9 & 78.1 \\
Removed (W) & & & & \\
\hline
\end{tabular}

\subsubsection{Thermal comfort}

According to the tested result, all the combinations could fulfill the requirement of removing $19.2 \mathrm{~W}$ extra heat from the manikin, but the further concern should be paid to the comfort. ASHRAE standard 55 
suggests a method of using operative temperature to determine the limits of local air speed. "Operative temperature is the uniform temperature of an imaginary black enclosure and air within it in which an occupant would exchange the same amount of heat by radiation plus convection as in the actual nonuniform environment." It is determined based on the local air temperature and mean radiant temperature [6]. In this study, the local operative temperature and air speed were collected along a vertical line 1.00 $\mathrm{cm}$ (0.39 in) away from the manikin. Figure 8 shows the simulation obtained operative temperature and air velocity in front of the manikin. The region enclosed by the solid (red) lines represents the acceptable conditions for thermal comfort [6]. The measured velocities for Cases A and B were lower than the upper limit $(1.2 \mathrm{~m} / \mathrm{s})$ while Case $\mathrm{D}$ and $\mathrm{E}$ were much higher. Case $\mathrm{C}$ showed a maximum velocity approximating to the limit. Moreover, because it is reported that supply air from a personalized ventilation system should have a temperature ranging from 23.0 to $26.0{ }^{\circ} \mathrm{C}\left(73.4-78.8{ }^{\circ} \mathrm{F}\right)$ to avoid significant discomfort to occupants [12], the selected combination used in the following study was Case C.
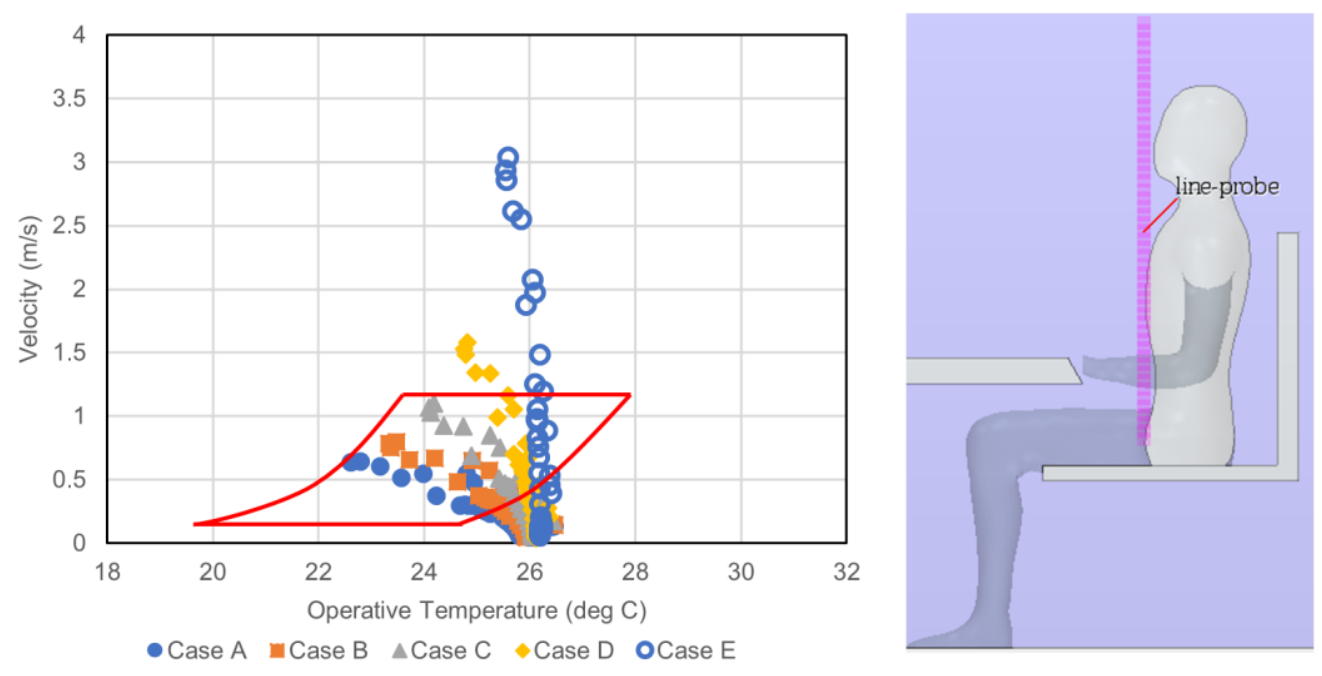

Figure 8 Local operative temperature and air velocity

\subsection{Evaluation of ATDs}

Once the supply condition is determined, the next challenge would be how to manage the air flow properly. A good ATD is supposed to have excellent performance on thermal comfort, perceived air 
quality, and ergonomics [40]. Many kinds of ATDs have been designed and studied by other researchers, for example, desk mounted ATDs[41], seat embedded ATDs [42][43], pillow ATDs [44], etc.. In this study, three types of desk mounted ATDs were selected and tested using the validated CFD model (Figure 1).

In the current section, the CFD model had the same configuration as used in the validation work. The computational domain represented a workstation for one office worker. The room's background temperature was maintained at $26.1{ }^{\circ} \mathrm{C}\left(79.0{ }^{\circ} \mathrm{F}\right)$ with an air exchange rate of $5 \mathrm{~h}^{-1}$ and the supply condition of the $\mu \mathrm{X}$ system is $0.014 \mathrm{~m}^{3} / \mathrm{s}(29.4 \mathrm{cfm})$ and $23.0^{\circ} \mathrm{C}\left(73.4^{\circ} \mathrm{F}\right)$. It was assumed that the office worker could move by the desk in a semicircle with a radius of $0.61 \mathrm{~m}(2.00 \mathrm{ft})$. The direction of the supply air could be adjusted for all the three ATDs.
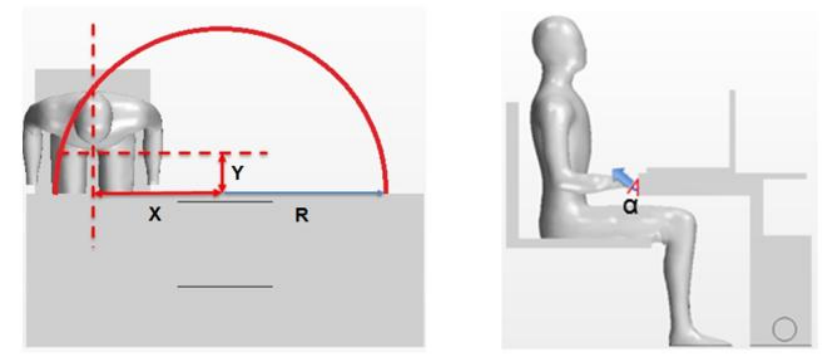

Figure 9 Movement range of the occupant (left) and the shooting angle of the ATDs (right)

The performance of the three ATDs was evaluated while the manikin was located within the movement range and the jet was shooting at different angles. Figure 10 illustrates the cooling performance of the Type I ATD while the manikin was sitting along the center line. Six different angles, $0^{\circ}, 5^{\circ}, 10^{\circ}, 20^{\circ}, 30^{\circ}$, and $40^{\circ}$ were tested. The optimal angle for cooling always lay between $0^{\circ}$ and $10^{\circ}$ regardless of the distance from the diffuser (Y). The most extra heat removed by the $\mu \mathrm{X}$ system while the manikin was sitting $0.20 \mathrm{~m}(0.66 \mathrm{ft}), 0.45 \mathrm{~m}(1.47 \mathrm{ft})$, and $0.61 \mathrm{~m}(2.00 \mathrm{ft})$ away from the desk was respectively $33.6 \mathrm{~W}$, $32.4 \mathrm{~W}$, and $30.3 \mathrm{~W}$. When the manikin was sitting very close to the desk $(0.20 \mathrm{~m} / 0.66 \mathrm{ft})$, the jet from 
the diffuser could work in a rather broad angle $\left(>40^{\circ}\right)$. Even when the manikin was sitting at the edge of the semicircular movement range, within $23^{\circ}$, the $\mu \mathrm{X}$ system would still work.

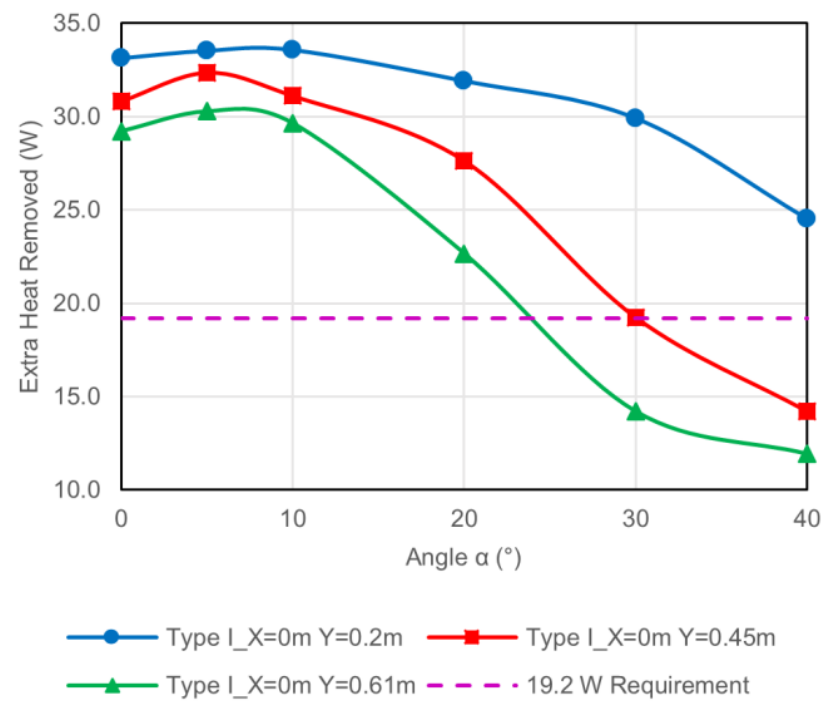

Figure 10 Cooling performance of Type I ATD shooting at different angles with the manikin sitting along the center line

Based on the results shown in Figure 10, the performance of the ATD was highly dependent on the target region which the jet blew onto. For those three locations, the target region of the jet moved upwards when the angle increased. Within $10^{\circ}$ the jet was always blowing to the stomach region. When the angle was increased to larger than $10^{\circ}$, the jet started to blow onto the chest, and the heat loss started to decrease. The extra heat removed by the jet was still higher than $19.2 \mathrm{~W}$ until the target zone moved to the upper part of the chest $\left(30^{\circ}\right.$ for $Y=0.45 \mathrm{~m} / 1.47 \mathrm{ft}$ and $\mathrm{Y}=0.61 \mathrm{~m} / 2.00 \mathrm{ft}$, Figure 11). After that, some part of the jet missed the human body and detoured around to the back of it. 


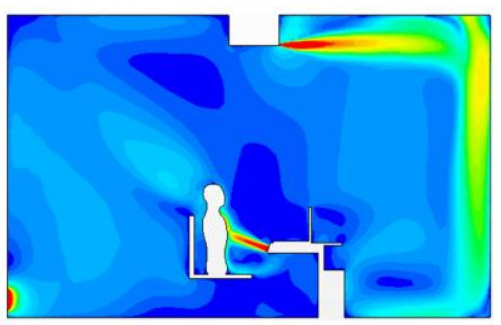

$X=0 m, Y=0.45 m, \alpha=20^{\circ}$

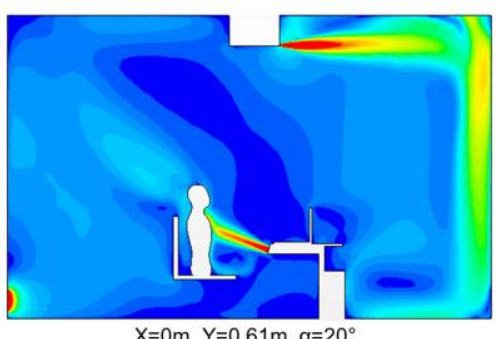

$X=0 \mathrm{~m}, Y=0.61 \mathrm{~m}, \alpha=20^{\circ}$

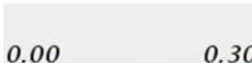

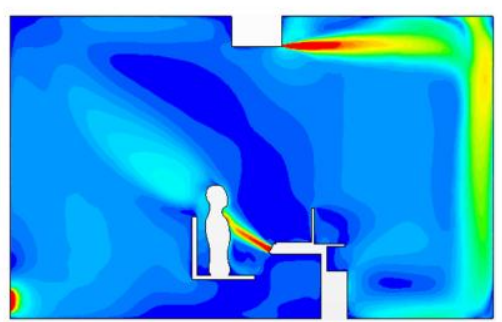

$X=0 m, Y=0.45 m, \alpha=30^{\circ}$

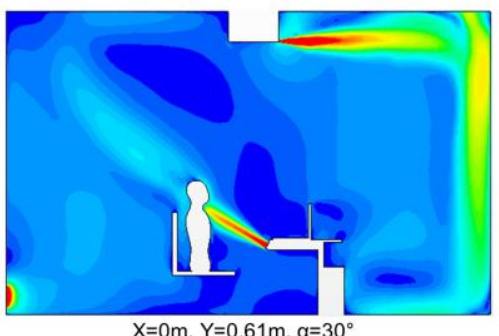

Velocity: Magnitude $(\mathrm{m} / \mathrm{s})$

$0.60 \quad 0.90$

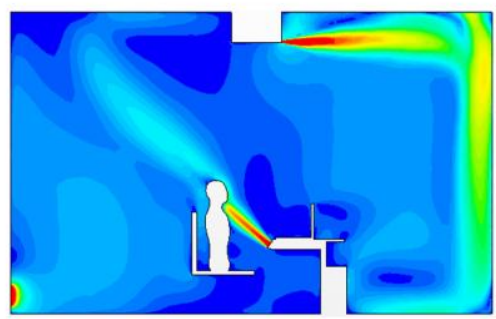

$X=0 m, Y=0.45 m, \alpha=40^{\circ}$

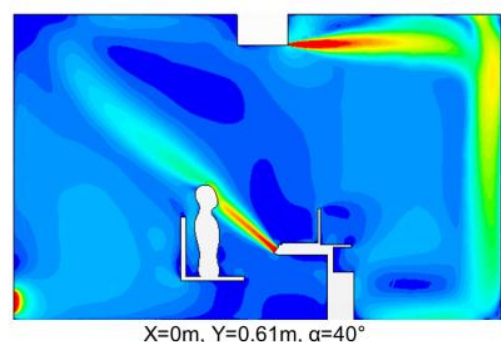

1.20

Figure 11 Velocity field at the symmetric plane of the manikin when it sits $0.45 \mathrm{~m}$ and $0.61 \mathrm{~m}$ away from

\section{the desk}

When the manikin was placed to one side, the jet had to be adjusted horizontally also. According to the previous results, the jet was always aimed at the stomach region to ensure the best cooling performance. The results were shown in Figure 12. The bold red figures indicated the best cooling performance of the jet shooting at the optimal angle at each location. For example, for Type I ATD, when the manikin was put $0.45 \mathrm{~m}$ away from the manikin, the column of data shown by the side of the black star of $0.45 \mathrm{~m}$ indicates the extra heat removed by the jet when the shooting angle was respectively $0^{\circ}, 5^{\circ}, 10^{\circ}, 20^{\circ}, 30^{\circ}$, and $40^{\circ}$ from the bottom to the top. The highest extra heat removed was obtained when the manikin sat in the 10-o'clock direction of the diffuser $\left(30^{\circ}\right.$ angle).

Similar studies have been done for the other two ATDs (Figure 12). For Type II and Type III ATDs, only the results of the jet shooting at the stomach were shown in the figure. It turns out that all three ATDs could fulfill the requirement to remove $19.2 \mathrm{~W}$ from the manikin. The worst scenario always appeared at 
the edge of the movement range. Among the three ATDs, Type I ATD worked the best in terms of the extra heat removed. 

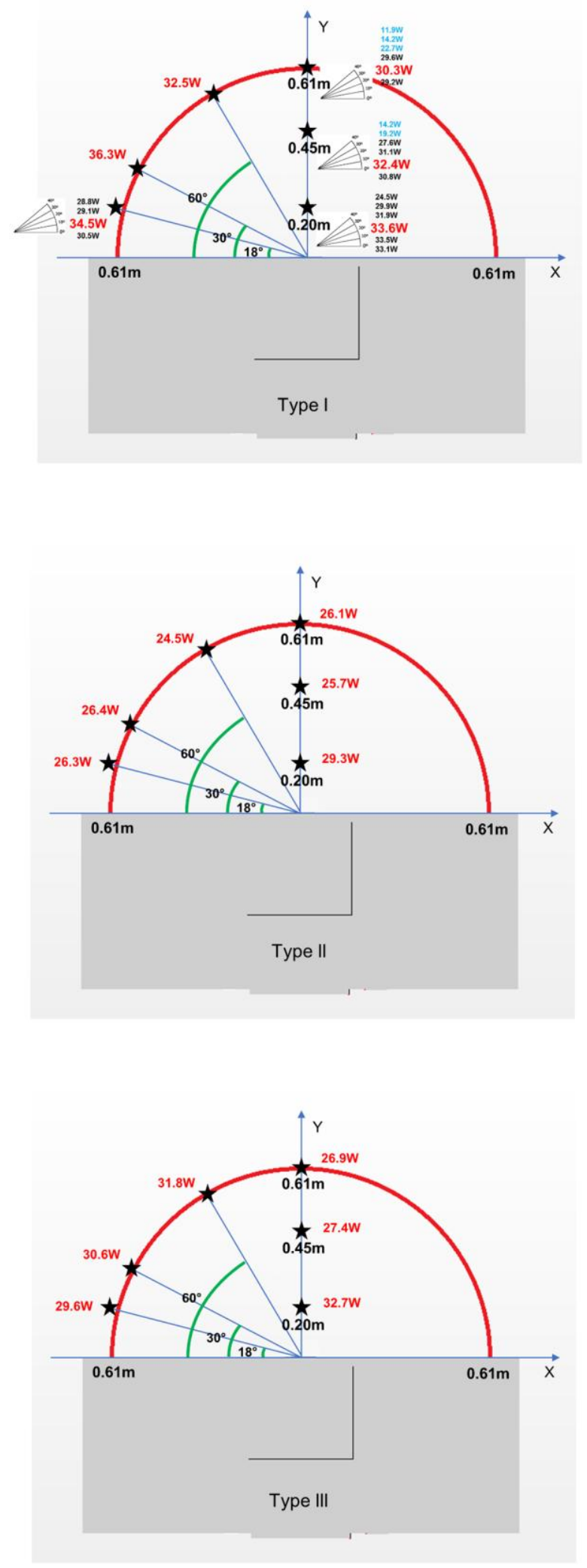


\section{Figure 12 Summary of the cooling performance of the three ATDs}

\subsection{Effect of furniture}

As mentioned by previous researchers [22], the presence of the furniture can influence the interaction between the thermal plume and the jet, resulting in a discrepancy in the performance of the jet. For example, the seat which the manikin sat on can prevent the thermal plume around the legs from rising up, leading to a weaker thermal plume around the upper part of the body. In this study, the effect of the seat backrest was evaluated. In the experiment, the manikin was sitting in a chair with a perforated backrest. Different from having a solid backrest, in this case, the jet was able to penetrate the backrest. So a case without a backrest was run and compared with the case with a solid backrest. The yellow line in Figure 6 shows the averaged heat flux of each segment in the case without the backrest, and the gray line shows the averaged heat flux of each segment in the case with a solid backrest. The comparison indicates a difference in the heat flux $\left(\sim 10 \mathrm{~W} / \mathrm{m}^{2}\right)$ from the back. Figure 13 shows the velocity field behind the manikin, and it is believed that with the solid backrest, the air which came to the back of the manikin was split into two portions. One was transported away from the manikin, and the other one was converged to the center of the back. However, without the solid backrest, most of the jet was converged to the region behind the back and took more heat from the back. Therefore, the solid backrest provided some "insulation" to the people, especially when the people was laid back. This "insulation" protects the people from being cold in cold environment but may exacerbate the discomfort in a hot environment. In addition to the backrest, it is noted that factors such as chair handles, clothing, and hair, can also influence the heat transfer by changing the surface temperature, creating obstacles for the thermal plume and even changing the shape of the manikin. 

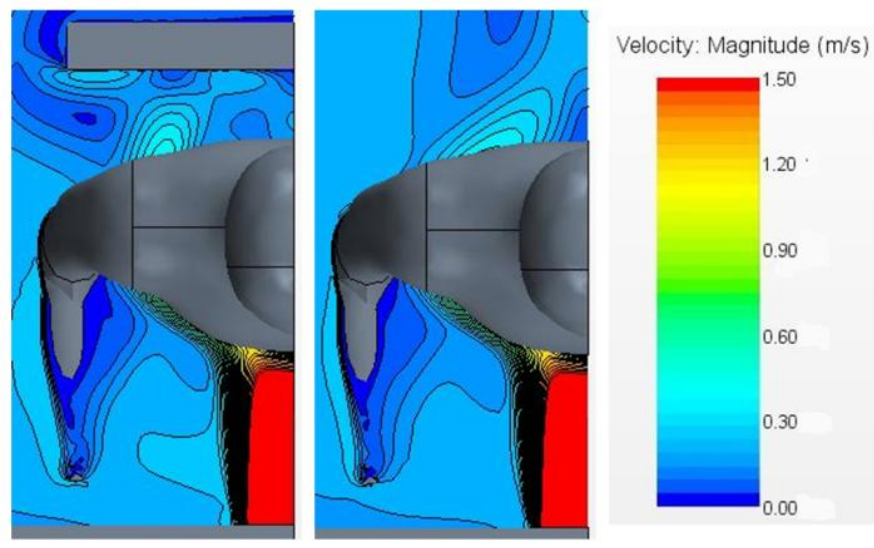

Figure 13 Velocity field behind the manikin

\subsection{Effect of the surface temperature}

As mentioned in Section 3.1, in addition to the turbulence-model effect as noted by previous work [39], the discrepancy between the experimental and CFD results was possibly because of the non-uniform temperature distribution on the manikin surface. The CFD simulation used constant surface temperature on the manikin skin. To properly validate the CFD model, the experiment should have had the same setting as the CFD simulation. However, creating an absolutely uniform surface temperature on a manikin in the experiment is almost impossible, since it is impractical to monitor and control the temperature of every point of the manikin's surface. The manufacturer states that "every segment of the manikin has one distributed sensor wire, zig-zagging the entire area of the segment. The accuracy of measurement and control of the temperature is $\pm 0.1{ }^{\circ} \mathrm{C}$ ". But much larger differences have been found during the experiment. In order to show that, a thermocouple was used to measure the surface temperature of the manikin during the experiment (Figure 14). 

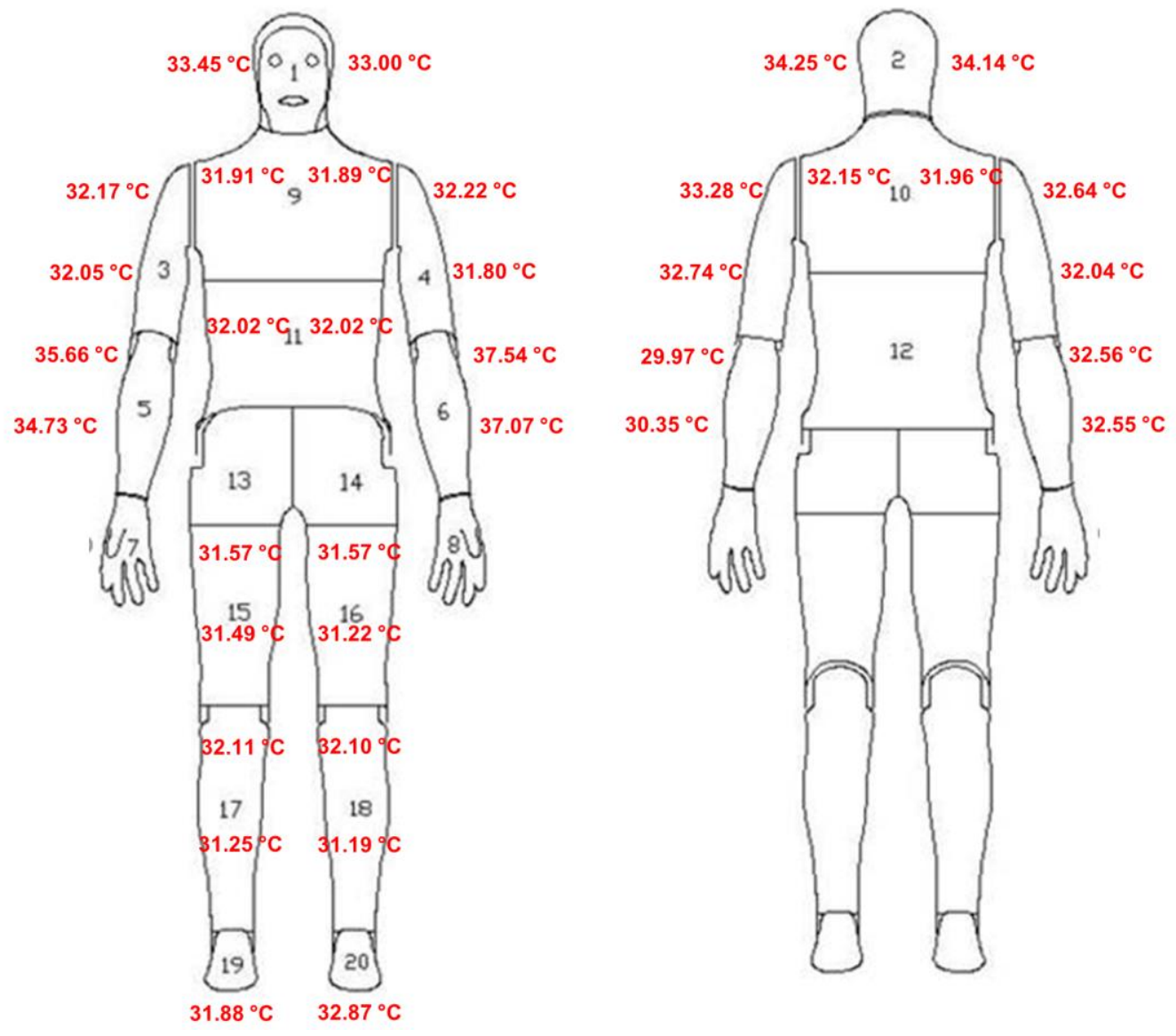

Figure 14 Surface temperature measurement on the manikin

The surface temperature within one segment was found to vary quite a bit. The smallest one was found on the stomach, while the largest one was found on the left forearm. Since only very limited numbers of points were measured for each segment, it may not be able to represent the true variance, but it still proved that the surface temperature was non-uniform. A clearer surface temperature distribution on the manikin could be seen by using a thermal camera (Figure 15). The non-uniform surface temperature distribution was confirmed, and at least a $1.0^{\circ} \mathrm{C}$ surface temperature difference was found on almost all the segments. Each segment always had a higher temperature in the central part and lower temperature at the edge. 


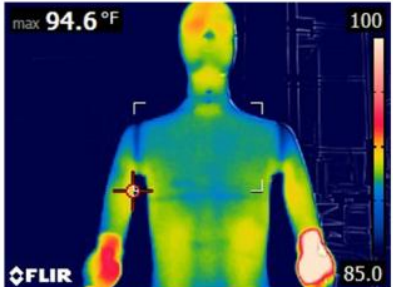

(a)

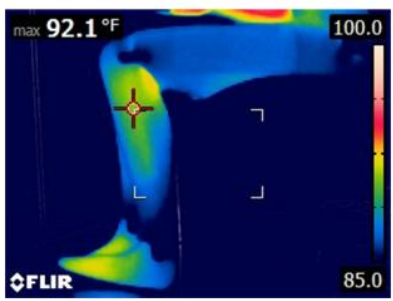

(c)

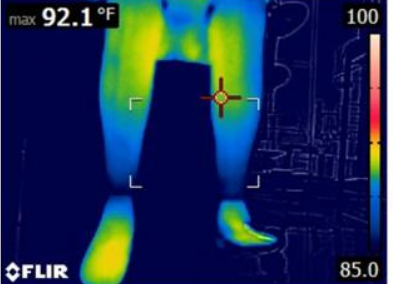

(b)

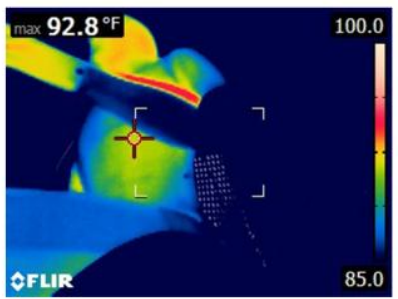

(d)

Figure 15 Surface temperature distribution on the manikin

The difference between the measured surface temperature and temperature set-point has also been observed (Figure 14, Figure 15). Average values of the measured surface temperature were used to represent the temperature for each segment. More segments were experiencing a higher temperature than the set-point (Table 3).

Table 3 Comparison between set-point temperature and measured temperature

\begin{tabular}{llll}
\hline & Set-point Temp., ${ }^{\circ} \mathrm{C}$ & Measured Temp., ${ }^{\circ} \mathrm{C}$ & Temp. Difference, ${ }^{\circ} \mathrm{C}$ \\
\hline Face & 33.89 & 33.23 & -0.66 \\
Head & 33.89 & 34.20 & 0.31 \\
Shoulder & 31.67 & 32.06 & 0.39 \\
Chest & 31.67 & 31.90 & 0.23 \\
Back & 31.67 & 32.06 & 0.39 \\
Stomach & 31.67 & 32.02 & 0.35 \\
Right Upperarm & 31.67 & 32.23 & 0.56 \\
Left Upperarm & 31.67 & 32.51 & 0.84 \\
Right Forearm & 33.89 & 33.88 & -0.01
\end{tabular}




$\begin{array}{llll}\text { Left Forearm } & 33.89 & 33.73 & -0.16 \\ \text { Right Thigh } & 31.67 & 31.46 & -0.21 \\ \text { Left Thigh } & 31.67 & 31.46 & -0.21 \\ \text { Right Calf } & 31.67 & 31.68 & 0.01 \\ \text { Left Calf } & 31.67 & 31.65 & -0.02 \\ \text { Right Foot } & 31.67 & 31.88 & 0.21 \\ \text { Left Foot } & 31.67 & 32.87 & 1.20\end{array}$

Note: Red value means the measured temperature is higher than the set-point;

blue value means the measured temperature is lower than the set-point.

In order to show the effect of the surface temperature on the heat loss of the manikin, a CFD case using the measured surface temperature was run to compare with the case using the set-point temperature. A better agreement was found by using the measured surface temperature. The difference of total heat loss between the CFD and experiment was reduced from $4.6 \mathrm{~W}$ to $2.1 \mathrm{~W}$ compared with the case using setpoint temperature. This study indicates that accurate prediction of the heat loss from the manikin requires a surface temperature that is as close to the experiment as possible.

\subsection{Other Considerations}

The application of the ATDs is not only based on physical measurement, such important factors as ergonomics and aesthetics could also play an important role in human judgment and general perception [40]. Among the three ATDs tested, the Type I ATD worked the best since it could remove the most extra heat from the manikin with the same amount of cooling power. However, it may interfere with people's thighs and bring some difficulties if people use a keyboard tray. The round panel (Type II ATD) was reported to be able to provide thermal comfort as well as perceived air quality [40], but implementing this type of ATD requires drilling a hole on the desk to connect the diffuser with the $\mu \mathrm{X}$ system which can be disruptive and unfavorable. Type III ATD leaves more space under the desk, and also avoids making any modification to the furniture. However, this kind of diffuser needs more complex duct connection and may have the problem of balancing the air of two openings. 


\section{Conclusions}

A CFD model has been developed, validated and applied to evaluate the performance of three types of ATDs selected for a micro-environment control $(\mu \mathrm{X})$ system. It was found:

1) The CFD-predicted heat loss from the manikin agreed within $6 \%$ of the measured results from the full-scale chamber tests. In addition, it was found that the heat loss of the manikin was very sensitive to the furniture placement and surface temperature of the manikin.

2) Convective heat transfer coefficients of all the segments of the manikin were calculated in the current work and compared with previous studies. The difference in height, surface area, and shape of the manikin could change the development of the thermal boundary layer and thus the convective heat transfer coefficient. However, more discrepancy was due to the methods of measurement.

3) Cooling performance increased more by increasing the supply air velocity than reducing the supply air temperature when the total cooling power is constant. Considering the extra heat removed and discomfort caused by the jet, the combination of $23.0{ }^{\circ} \mathrm{C}\left(73.4{ }^{\circ} \mathrm{F}\right)$ supply air temperature and $0.014 \mathrm{~m}^{3} / \mathrm{s}(29.4 \mathrm{cfm})$ flow rate was recommended as the operating condition of the micro-environment control $(\mu \mathrm{X})$ system.

4) The performance of three types of ATDs was evaluated using the validated CFD model over a semicircle range of $0.61 \mathrm{~m}$ radius around the $\mu \mathrm{X}$ diffuser. The manikin could be cooled sufficiently in the movement range using all the three ATDs, while Type I ATD worked the best. The cooling performance of the ATDs is highly dependent on the shooting angle (target area). The best performance was always achieved when the jet was blown onto the stomach of the manikin.

5) One of the three ATDs will be selected to be incorporated into the $\mu X$ system. The final product will be tested with a thermal manikin and 32 human subjects in the near future. More discussion 
in terms of thermal sensation and comfort for each individual body part, draft effect, perceived air quality is going to be addressed based on more measurements and evaluation of the subjects.

\section{Acknowledgement}

The information, data, or work presented herein was through a research project funded in part by the Advanced Research Projects Agency-Energy (ARPA-E), U.S. Department of Energy, under Award Number DE-AR0000526. The views and opinions of authors expressed herein do not necessarily state or reflect those of the United States Government or any agency thereof.

\section{Reference}

[1] H. Zhang, E. Arens, Y. Zhai, A review of the corrective power of personal comfort systems in non-neutral ambient environments, Build. Environ. 91 (2015) 15-41.

doi:10.1016/j.buildenv.2015.03.013.

[2] EIA, EIA - Annual Energy Outlook 2014 Early Release, (n.d.). https://www.eia.gov/forecasts/aeo/tables_side.cfm (accessed March 10, 2014).

[3] S. Karjalainen, Thermal comfort and gender: A literature review, Indoor Air. 22 (2012) 96-109. doi:10.1111/j.1600-0668.2011.00747.x.

[4] J. Kim, R. de Dear, C. Candido, H. Zhang, E. Arens, Gender differences in office occupant perception of indoor environmental quality (IEQ), Build. Environ. 70 (2013) 245-256. doi:10.1016/j.buildenv.2013.08.022.

[5] M. Indraganti, R. Ooka, H.B. Rijal, Thermal comfort in offices in India: Behavioral adaptation and the effect of age and gender, Energy Build. 103 (2015) 284-295.

doi:10.1016/j.enbuild.2015.05.042. 
[6] American Society of Heating Refrigerating and Air-Conditioning Engineers, ASHRAE 55 Thermal environmental conditions for human occupancy, (2013).

[7] C. Huizenga, S. Abbaszabeh, L. Zagreus, E.A. Arens, Air quality and thermal comfort in office buildings : Results of a large indoor environmental quality survey Air Quality and Thermal Comfort in Office Buildings :, in: Heal. Build. 2006, Healthy Buildings, Lisboa; Portugal, 2006.

[8] H. Zhang, Human thermal sensation and comfort in transient and non-uniform thermal environments, University of California, Berkeley, 2003. doi:10.1016/j.enbuild.2013.06.009.

[9] E. Arens, H. Zhang, C. Huizenga, Partial- and whole-body thermal sensation and comfort - Part II: Non-uniform environmental conditions, J. Therm. Biol. 31 (2006) 60-66. doi:10.1016/j.jtherbio.2005.11.027.

[10] M. Kong, J. Zhang, J. Wang, Air and air contaminant flows in office cubicles with and without personal ventilation: A CFD modeling and simulation study, Build. Simul. 8 (2015) 381-392. doi:10.1007/s12273-015-0219-6.

[11] J. Kaczmarczyk, a Melikov, P.O. Fanger, Human response to personalized ventilation and mixing ventilation., Indoor Air. 14 Suppl 8 (2004) 17-29. doi:10.1111/j.1600-0668.2004.00300.x.

[12] A.K. Melikov, Personalized ventilation, Indoor Air, Suppl. 14 (2004) 157-167. doi:10.1111/j.1600-0668.2004.00284.x.

[13] A.K. Melikov, B. Krejciríková, J. Kaczmarczyk, M. Duszyk, T. Sakoi, Human response to local convective and radiant cooling in a warm environment, HVAC\&R Res. 19 (2013) 1023-1032. doi:10.1080/10789669.2013.842734.

[14] A.F. Mills, Heat Transfer, Second, Prentice Hall, Inc., Upper Saddle River, NJ, 1999.

[15] T. Hoyt, E. Arens, H. Zhang, Extending air temperature setpoints: Simulated energy savings and design considerations for new and retrofit buildings, Build. Environ. 88 (2014) 89-96. 
doi:10.1016/j.buildenv.2014.09.010.

[16] T. Hoyt, K.H. Lee, H. Zhang, E. Arens, Tom Webster, Energy savings from extended air temperature setpoints and reductions in room air mixing, in: Int. Conf. Environ. Ergon., Boston, 2009: pp. 0-5. doi:10.1016/j.enbuild.2013.06.009.Keywords.

[17] H.E. Khalifa, M. Koz, Numerical investigation of the freezing of a phase change material in a thermal storage device with an embedded evaporator, in: ASME 2016 Summer Heat Transf. Conf., Washington D.C., 2016: pp. 1-7.

[18] M. Koz, H.S. Erden, H.E. Khalifa, Numerical investigation of the melting of a phase change material in a thermal storage device with embedded air flow channels, in: ASME 2016 Summer Heat Transf. Conf., Washington D.C., 2016: pp. 1-7.

[19] ARPA-E, Delivering efficient local thermal amenities (DELTA) FOA, Washington D.C., 2014.

[20] American Society of Heating Refrigerating and Air-Conditioning Engineers, ASHRAE Handbook-Fundamentals Chapter 18 Nonresidential Cooling and Heating Load Calculations, (2013).

[21] Y. Cheng, J. Niu, N. Gao, Thermal comfort models: A review and numerical investigation, Build. Environ. 47 (2012) 13-22. doi:10.1016/j.buildenv.2011.05.011.

[22] R.K. Dygert, T.Q. Dang, J.S. Russo, H.E. Khalifa, Modeling of the human body to study the personal micro environment., HVAC\&R Res. 115 (2009). http://www.thefreelibrary.com/Modeling+of+the+human+body+to+study+the+personal+micro+en vironment.-a0217848220.

[23] Y. Houdas, E. Ring, Human Body Temperature: Its measurement and regulation, Plenum Press, New York, n.d.

[24] J.S. Russo, T.Q. Dang, H.E. Khalifa, Computational analysis of reduced-mixing personal 
ventilation jets, Build. Environ. 44 (2009) 1559-1567. doi:10.1016/j.buildenv.2008.11.005.

[25] R. de Dear, E.A. Arens, H. Zhang, M. Oguro, Convective and radiative heat transfer coefficients for individual human body segments, Int. J. Biometeorol. 40 (1997) 141-156. doi:10.1080/09613218.2011.556008.

[26] D.N. Sørensen, L.K. Voigt, Modelling flow and heat transfer around a seated human body by computational fluid dynamics, Build. Environ. 38 (2003) 753-762. doi:10.1016/S03601323(03)00027-1.

[27] J. Yang, S. Kato, J. Seo, Evaluation of the convective heat transfer coefficient of the human body using the wind tunnel and thermal manikin, (2009) 563-569.

[28] M. Kong, J. Zhang, B. Guo, K. Han, Measurements of grease emission and heat generation rates of electric countertop appliances (RP-1631, part 1), Sci. Technol. Built Environ. 4731 (2016) 1-21. doi:10.1080/23744731.2016.1197749.

[29] H. Nilsson, H. Brohus, P. V Nielsen, Annex 20: Benchmark test for a computer simulated person manikin heat loss for thermal comfort evaluation, 2007. http://www.cfd-benchmarks.com/.

[30] G. Cao, P. V. Nielsen, R.L. Jensen, P. Heiselberg, L. Liu, J. Heikkinen, Protected zone ventilation and reduced personal exposure to airborne cross-infection, Indoor Air. 25 (2015) 307-319. doi:10.1111/ina.12142.

[31] Z. Bolashikov, A. Melikov, M. Krenek, Control of the free convective flow around the human body for enhanced inhaled air quality: Application to a seat-incorporated personalized ventilation unit, HVAC\&R Res. 16 (2010) 161-188. doi:10.1080/10789669.2010.10390899.

[32] D. Licina, J. Pantelic, A. Melikov, C. Sekhar, K.W. Tham, Experimental investigation of the human convective boundary layer in a quiescent indoor environment, Build. Environ. 75 (2014) 79-91. doi:10.1016/j.buildenv.2014.01.016. 
[33] Z. Zhang, W. Zhang, Z.J. Zhai, Q.Y. Chen, Evaluation of various turbulence models in predicting airflow and turbulence in enclosed environments by CFD: Part 2-comparison with experimental data from literature, HVAC\&R Res. 13 (2007) 871-886. doi:10.1080/10789669.2007.10391460.

[34] W. Liu, J. Wen, C.H. Lin, J. Liu, Z. Long, Q. Chen, Evaluation of various categories of turbulence models for predicting air distribution in an airliner cabin, Build. Environ. 65 (2013) 118-131. doi:10.1016/j.buildenv.2013.03.018.

[35] L. Peng, P. V. Nielsen, X. Wang, S. Sadrizadeh, L. Liu, Y. Li, Possible user-dependent CFD predictions of transitional flow in building ventilation, Build. Environ. 99 (2016) 130-141. doi:10.1016/j.buildenv.2016.01.014.

[36] R.K. Dygert, Mitigation of cross-contamination in an aircraft cabin through the use of localized exhaust, Syracuse University, 2010.

[37] J. Russo, A Detailed and Systematic Investigation of Personal Ventilation Systems, Syracuse University, 2011.

[38] L. Wang, J. Zhang, X. Bai, M. Kong, Local heat flux distribution over human body : literature review and analysis, in: Roomvent 2014, Sao Paolo, 2014: pp. 1-10.

[39] N. Martinho, A. Lopes, M. Silva, CFD modelling of benchmark tests for flow around a detailed computer simulated person, 7 Th Int. Therm. Manikin Model. Meet. 2007 (2008) 3-8.

[40] J. Kaczmarczyk, A. Melikov, Z. Bolashikov, L. Nikolaev, P.O. Fanger, Human response to five designs of personalized ventilation, HVAC\&R Res. 12 (2006) 367-384. doi:10.1080/10789669.2006.10391184.

[41] A.K. Melikov, R. Cermak, M. Majer, Personalized ventilation: evaluation of different air terminal devices, Energy Build. 34 (2002) 829-836. doi:10.1016/S0378-7788(02)00102-0.

[42] M. Kong, J. Zhang, P.V. Nielsen, J. Wang, L. Wang, Experimental study of chair ventilation in 
office cubicles, in: Roomvent 2014, Sao Paolo, 2014.

[43] P. Nielsen, N. Bartholomaeussen, E. Jakubowska, H. Jiang, O. Jonsson, K. Krawiecka, A. Mierzejewski, S. Thomas, K. Trampczynska, M. Polak, M. Soennichsen, Chair with integrated personalized ventilation for minimizing cross infection, in: Proc. Roomvent, 2007. http://scholar.google.com/scholar?hl=en\&btnG=Search\&q=intitle:Chair+with+integrated+persona lized+ventilation+for+minimizing+cross+infection\#0.

[44] P. Nielsen, E. Barszcz, T. Czarnota, The influence of draught on a seat with integrated personalized ventilation, in: Int. Conf. Indoor Air Qual. Clim., Copenhagen, 2008: p. 2. http://scholar.google.com/scholar?hl=en\&btnG=Search\&q=intitle:The+Influence+of+Draught+on $+\mathrm{a}+$ Seat+with+Integrated+Personalized+Ventilation\#0. 